\title{
Access to Waterfront Landscapes FOr Tourists LiVing With DisabiLities
}

\author{
Gabriella Szaszák $^{1}$, Albert Fekete ${ }^{2}$ and Tibor Kecskés ${ }^{3}$ \\ ${ }^{1}$ Faculty of Landscape Architecture and Urbanism, Szent Istvan University, Budapest, Hungary \\ szaszakg@gmail.com \\ ${ }^{2}$ Faculty of Landscape Architecture and Urbanism, Szent Istvan University, Budapest, Hungary \\ fekete.albert@tajk.szie.hu \\ ${ }^{3}$ Studio for Architecture and Interior Design (www.kecskestibor.hu) \\ tkecskes@yahoo.com
}

\begin{abstract}
In this paper an overview on the inclusive spatial design tools providing equal access to waterfront landscapes for tourists living with disabilities will be given. The focus is on close-to-natural areas which are popular because of their recreational potential. These areas present special natural and landscape values, and mostly are ecologically vulnerable. In these important ecological surroundings human presence and landscape values must be harmonized.

Environmental conditions, legal requirements and the economic situation can limit the opportunity for comprehensive access, but keep disability in mind while designing and maintaining these sites is a potential to provide wider access to the waterfront tourist destinations. We are about to present model solutions keeping the environment totally or mostly in its original, natural condition, but allowing recreational activities in the site at the same time.
\end{abstract}

Keywords: inclusive landscape design, landscape architecture, disability, accessibility, waterfront tourism

\section{INTRODUCTION}

Waterfront landscapes with ecological values often are popular tourist destinations because of their natural beauty. The naturalness shown mainly by the level of biodiversity invites people engaging physical outdoor activities [2], and this way nature contributes to human well-being, and provides health benefits for all [17]. At the same time, in ecologically important sites nature protection is also a priority. Therefore, if the protection is not so strict and human presence can be allowed, awareness of the natural values must be raised. As the Hungarian Act on Nature Conservation in Hungary [9] puts it, it is essential to promote landscape values in order to protect them, and also to enable the educational and recreational use of these sites. Therefore it is of high importance to harmonize natural and human interest.

Based on the Hungarian population census of 2011 , about $4.6 \%$ of the population can be considered as physically restricted or handicapped (actual number: 457000) [14]. In addition, there are even more people affected by disability issues: the families and friends of people with disabilities are also involved when it comes to go on holiday.

The Ministry of Social Affairs commissioned the Motivation Foundation (Motiváció Alapítvány) 
and its partner, the Revita Foundation to conduct a research on "tourist habits and needs of people with disabilities". The basic objectives of the research program was to inquire the travelling habits and special needs of people with disabilities in order to propose guidelines and services for tourism industry for proper accommodation and fulfilment of these needs of the people living with disabilities. The research including the four most typical disability groups with motor, visual, hearing or mental disabilities administered 1000 questionnaires to subjects whose age was within the working age group (15-64 years old) and it was followed by personal interviews.

Research has shown - among other findings - that in Hungary the tourism opportunities for people with disabilities, habits and needs of the individual components differ significantly in some aspects from the general population, and people with disabilities do demand travel opportunities. Moreover - which might be surprising - people with disabilities like to travel in some aspect more than other people. Slightly less than $90 \%$ of people with disabilities of the sample travelled as tourists in the previous 2 years either domestically or abroad. About half of the responders used railings, handrails and ramps during the tourism programs.

The research highlights that in all disability groups the waterfront recreation is one of the most popular tourist attraction and recreation destination. It is not only the current practice, but also characterizes the preferences of travellers with disabilities [18].

The results of the research have landscape architecture perspective as well. For spatial planners and landscape designers it is important to examine the points of interests of people with disabilities, their travelling habits, motivations for excursions. The landscape architects should take into the account the deficiencies of infrastructure of natural or semi-natural areas that make travelling impossible or very difficult for people with disabilities. The results and conclusions of this research can broaden the expert knowledge on how to bring people with disabilities closer to the nature without damaging or degrading the important ecological areas and their unique or highly valued environmental features or making them disappear from the site.

\section{MATERIAL AND METHODS}

The authors are active spatial designers in the fields of landscape architecture, architecture, interior design and civil engineering, so the issue is examined from different scales and perspectives [4, 5]. Our focus is on inclusive design. The shown design tools and examples are collected from our design practices and research. Our aim is to show opportunities to other designers whether and how is it possible to provide access to tourist and recreational destinations for all [7, 8]. Careful design and the sensitive adaptation of the spatial solutions are the keys for a more inclusive environment, even when equal access cannot be fully realized. In summary, this research, using the universal design means and systems, presents planning and design tools of architecture, landscape architecture, other design specialties and civil engineering which are widely used in some European countries, in the United States and Canada $[1,17]$ in order to be able to accommodate people with disabilities who can get a more complete travelling, participation and nature experience.

\section{PHILOSOPHICAL AND SOCIAL CONTEXT AND THE GRAMMAR OF DESIGN}

The topic of equal accessibility leads us into the deep regions of philosophy in strong relation to linguistic approaches. Examining natural human languages, as tools for communication, linguistics agree that the use of languages should be transparent [20]. What do they mean by transparency? Transparency in this meaning is a beneficial property not disturbing the transmitted information. Linguistic transparency is a sensitive balance between visibility and 
non-visibility. Obviously there is a need for a certain level of physical effects as the base of communication, but all the effects beyond these basic needs are disadvantageous and confusing. Language should play its roll as transmitting the information, but shouldn't be noticed as a separated entity. Language plays the best roll, when it is transparent, when it is imperceptible as a tool.

Applying this linguistic metaphor to design aiming equal access, we must claim, that the best solutions are invisible in the same way, as we defined above. The only organic way to be invisible is to integrate the topic into social and professional levels of the everyday use. At the social scene - referring the famous model of evolution biologist Richard Dawkins - we should develop wellfunctioning memes [3], those could spread in the space of social consciousness and become integrated component of the everyday discussions. Memes, the cognitive "genes" of human thinking can be very effective and can become replicators like biological genes, multiplying themselves in the "infected" structures. Referring another classic comment of "meaning is use" [21], the best method to give the right and effective meaning of "equal accessibility" or "environmental awareness" is evidently to overwhelm the space of everyday discussions with the current uses of the expression as well as the linked practical manifestations. This way we can gain an evident, integrated, in other word: transparent social communicational tool and we are able to handle the problems of people living with disabilities or the issues of sustainable landscape management.

In the field of design we can also apply the metaphor of transparency. Effective design is organic, as Frank Lloyd Wright puts it: developing from the bottom to the top [22]. The proper design solutions should follow the same rules than a language in human communication: on the one hand they should serve the current function and for this they should be "visible", but it should be a limited visibility, therefore on the other hand proper design solutions should play their tool-roll, and as tools should remain invisible or transparent. For this purpose designers, architects and landscape architects should carefully examine all the social, physical, psychological, functional and technical circumstances of the current tasks, and should only gently answer all these questions in harmony with the widespread memes of the topic (see above). This way they can avoid one of the greatest enemies of all creative activities, what is overdesign [16]. Overdesign is a needlessly loud phenomenon, especially in those environments, where an important goal is to provide and protect the genuine, mostly silent values of nature.

\section{LEGAL CONTEXT}

In Hungary, accessibility requirements for people with disabilities mostly concern the built environment [10]. Although the modification of the equalization opportunity law in 2007 [11] shifted the focus from the physical barriers to a more general level of equal access including public services, there are still very few guidelines for constructions in the close-to-natural environment aiming to provide access for the public [12].

The accessibility of a site is influenced both by the individual abilities of the visitors and the physical conditions of the environment. Social exclusion and disadvantage of people with disabilities can be reduced if a careful and proper design is applied [19]. Disability can be compensated by using the adequate technical solutions and by enhancing the degree of participation in the community or society [15].

Equal access can be enhanced if the site is as barrier-free as possible, and the conditions are right for getting information and for being able to communicate. The semi-natural environment the more accessible is, nature and space the more intensively can be experienced. In Hungary "the built environment shall be considered accessible if convenient, safe and 
independent use is ensured for all persons." [10] In a close-to-natural environment this is a more complex issue, considering the ecosystems full of natural elements and features which cannot or must not be changed. But supported with proper social attitude there are possibilities to provide access also to ecologically vulnerable tourist destinations (e.g. waterfronts) for a broader range of individuals.

\section{SPECIAL NEEDS WITH DIFFERENT DISABILITIES}

\subsection{Mobility impairments}

The special needs of people living with mobility impairments are the followings:

- the surface and texture of the pavements

- the differences in level

- the angle of the slopes

- the size and space for approach and use

- the consideration of the reference dimensions of the human body

\subsection{Visual impairments}

The special needs of people living with visual impairments are the followings:

- the surface and texture of the pavements

- the differences in level

- warning of dangers

- signing of safe routes and guiding to destinations

- haptic and auditive information (it must be taken into consideration that in the outdoor environment haptic information like Braille texts can get dirty)

- obvious and strength visual signs

- contrast in light and colour

- legibility

- the size and space for approach and use

- the consideration of the reference dimensions of the human body

\subsection{Hearing impairments and mental disabilities}

- warning of dangers

- signing of safe routes and guiding to destinations

- obvious and strength visual signs

- contrast in light and colour

- use of pictograms

- legibility, simplicity, conciseness, transparency, consistency, clarity 
Concerning the surfaces, constructions, dimensions, materials etc., the general design principles should be taken into consideration. This paper aims to show the specific solutions which can be adapted to waterfront landscapes, and does not detail technical information.

\section{ACCESS TO WATERFRONT LANDSCAPES}

\subsection{Parking and approaching}

At the entrance of the site accessible parking places are necessary for cars, vans and - in the case of hosting visitor groups - buses. The area should be accessed by public transportation as well. The waterfront and other tourist attractions of the site must be available from the accessible parking places. At the entrances detailed information must be placed with the directions, attractions, basic services, wheelchair-accessible accommodations, routes and activities, etc., which can be founded in the site. If it is possible build accessible routes to the waterfront maximum after every $500 \mathrm{~m}$.
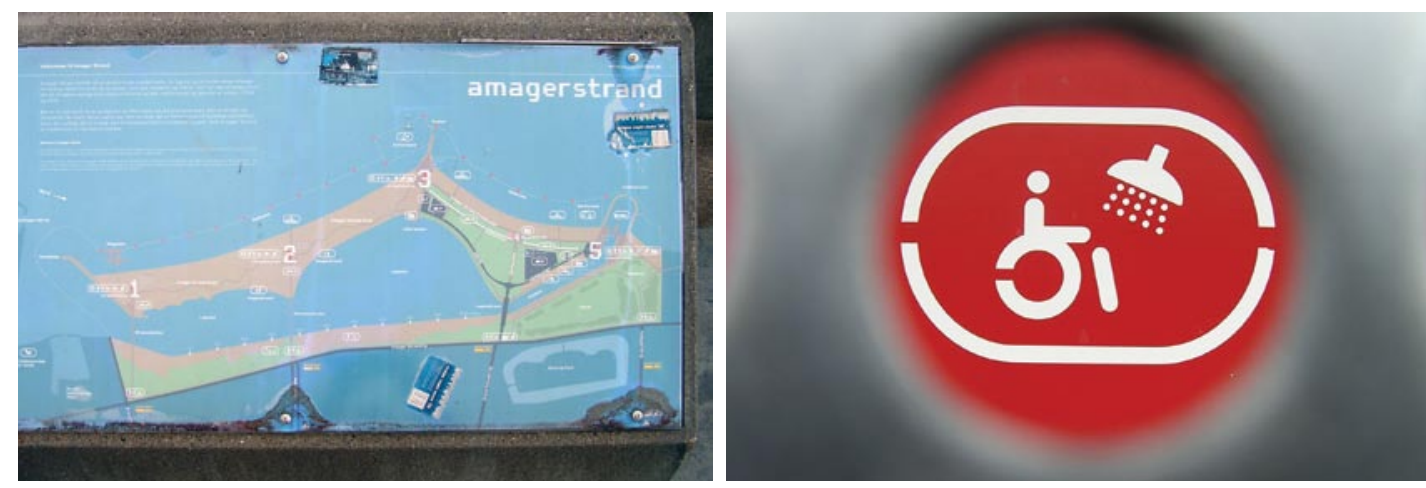

Figure 1. \& 2. Information at the entrances and signing all accessible services is of high importance

As we have mentioned, the differences in level are often obstacles for people living with disabilities. In addition, the elderly, or families with small children also may experience this handicap when walking with stick or baby stroller. It is an advantage of waterfronts that the bank of lakes, rivers and springs is often flat, and the elevation of the bank is non-existing or moderate. At the same time banks are often covered in sand or rocks, which can make it difficult to approach the water body, therefore compacted paths must be provided. These paths, walkways or bicycle roads are more convenient and preferred by able-bodied visitors as well. The material of these paths is mostly concrete, wood or - covering the parts in the water - metal stepping grid. Every construction must be stable - even pontoons must not swing. No slippery surfaces are affordable, and at this point we emphasize the importance of proper maintaining. 

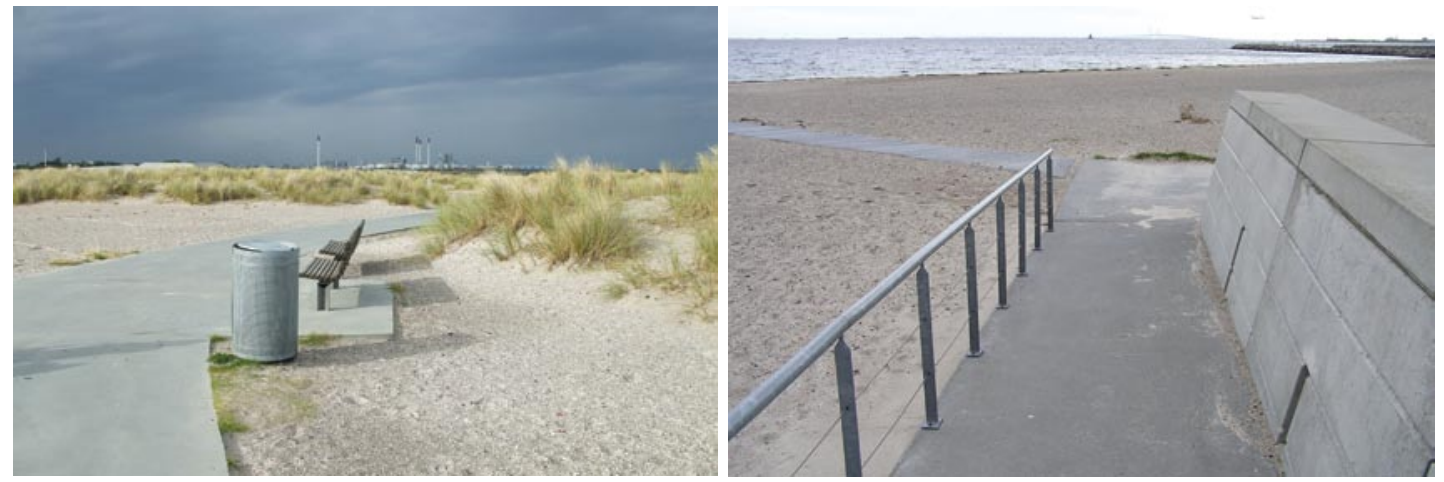

Figure 3. \& 4. Compacted paths are preferred by all visitors, because it is hard to walk or drive on soft surfaces like sand or gravel
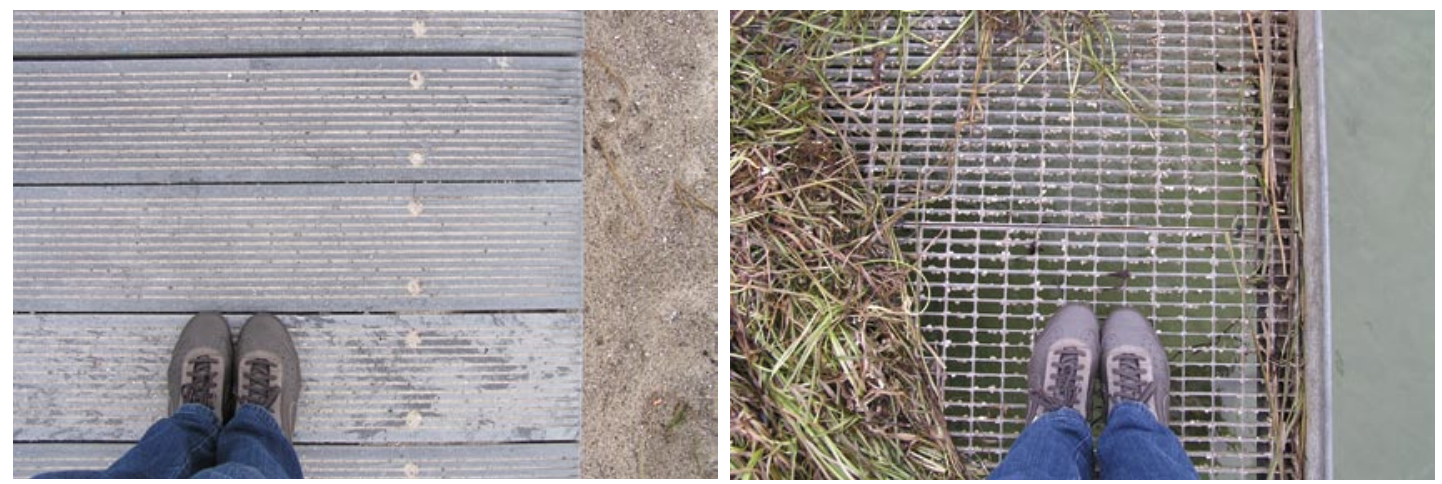

Figure 5. \& 6. Most often used materials on waterfront landscapes are concrete, wood and metal - besides the good quality, maintaining is also an important issue

\subsection{Bathing beaches, jetties and pontoons}

Natural bathing places are visited mostly in the summertime for water activities like swimming, boating and water sports. At the same time these sites often function as recreational areas for people who live in the neighbourhood during the whole year. Therefore trees and park furniture is needed. Benches should be placed in sunny and shady locations as well, because their use depends on the preferences of the visitors and also on the outdoor conditions like the season or the weather.

Services like wheelchair-accessible toilet, changing room and shower must be available [13]. These services should be close to each other and to the swimming place, and must be provided with accessible routes within the site. If it is possible to borrow a wheelchair for getting into the water, storage place for the own wheelchair of the visitor is necessary.

For entering the water, the following opportunities are convenient:

- gently sloping ramp with double handrails and metal stepping grid surface on the underwater parts (In this case, for wheelchair users a nother wheelchair is necessary in the water.)

- $\quad$ stairway with double handrails and metal stepping grid surface on the underwater parts 
- gently sloping mobile slide (In this case the visitors with disabilities need assistance, and the suitable changing point for sitting from the chair to the slide must be provided.)

- pool lift (In this case the visitors with disabilities need assistance.)
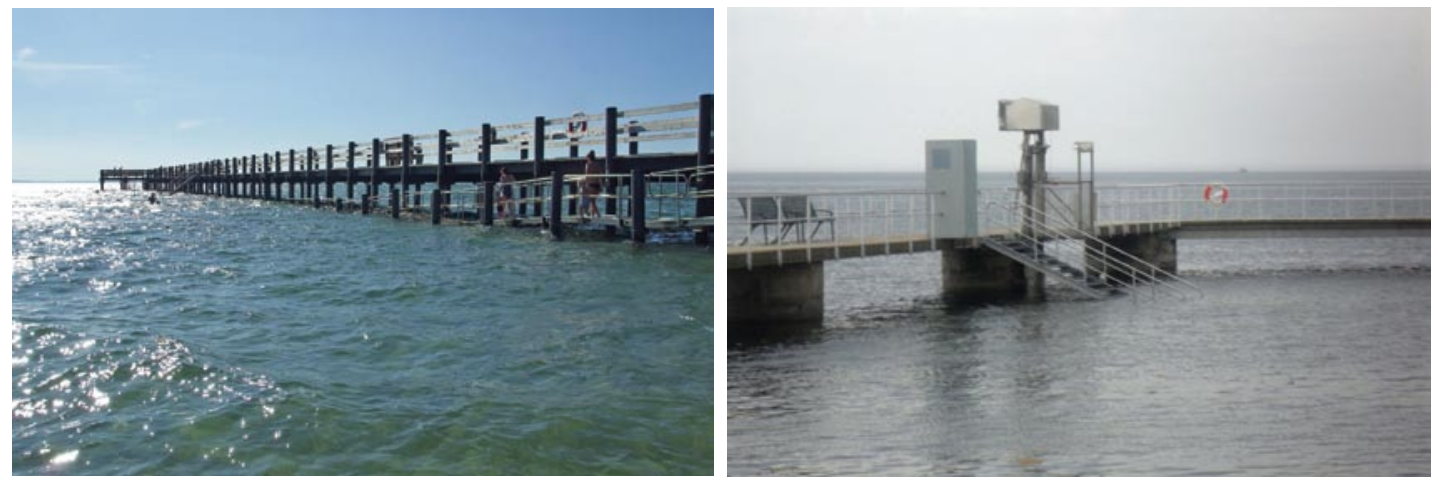

Figure 7. \& 8. Access to the water via from a wooden jetty via ramp, staircase and pool lift
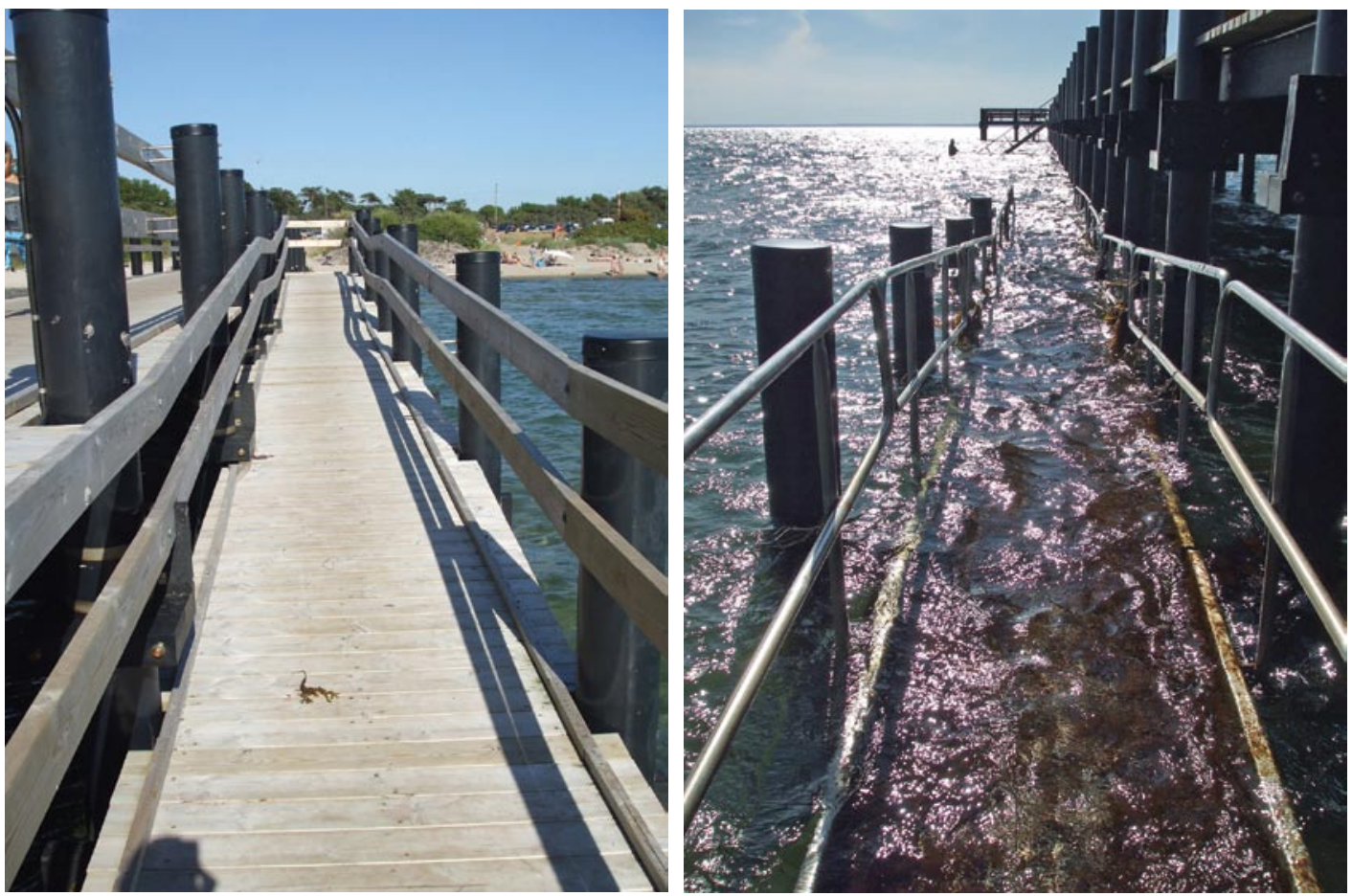

Figure 9. \& 10. The jetty is a wood construction with safety railings and edges, and the underwater part is a metal construction

Bathing pontoons should be as stable as possible, and must be equipped with safety railings. The level difference between the water surface and the pontoon's or jetty's surface should be moderate, and so should be the level difference between the bank and the pontoon or jetty. [17] 


\subsection{Fishing places}

Fishing places suitable for the use by people with disabilities should not be separated from average fishing places in order to integrate all visitors. Sitting furniture can be placed, but leave barrier-free space for wheelchair users. If possible let an area with a diameter of $10 \mathrm{~m}$ free from vegetation (e.g. trees or reed) in order to avoid the hook or the line getting caught. Because of the lower level of mobility and the lack of trees rain- and wind-shelters are necessary for these fishing places. The jetty must be equipped with edging and safety railing, at least on the wheelchair-accessible part. The railing should be a little bit smaller as sitting people use it for fishing who are not able to stand up when caught a fish. $[6,17]$
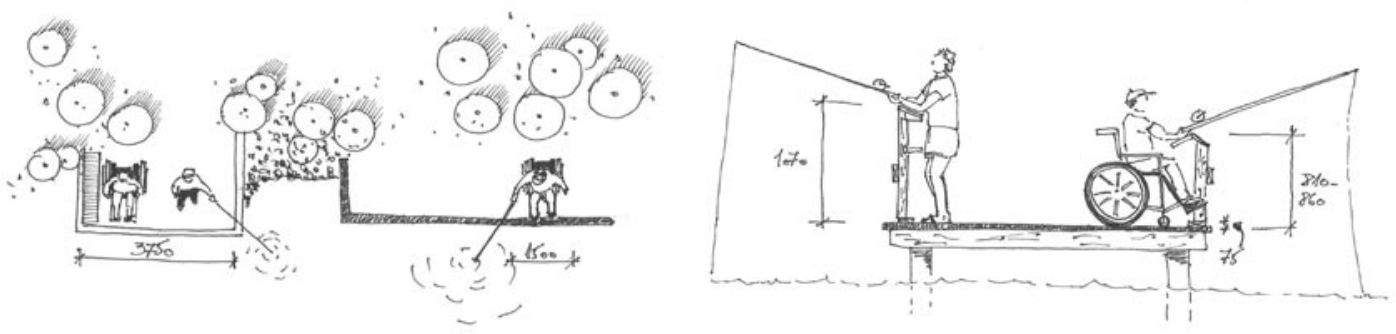

Figure 11. \& 12. Wheelchair-accessible fishing places integrated with average fishing places

\section{CONCLUSION}

Waterfront landscapes are popular tourist destinations among people, incuding those who live with some disablity. At the same time these areas are sensitive ecosystems, and therefore minimal interventions should be applied when providing access to them. As we have shown, the general design tools with little adaptations or even only with careful design can ensure the access for a wider range of visitors. The examples in this paper are good examples from abroad, but these technical solutions can be applied in other part of the world, also in Hungary and other European countries. If inclusive design and nature conservation principles are taken into consideration from the very beginning of the whole design process, access to waterfront landscapes can be spreaded, and the natural values of the landscape remain existing and provide the experience of nature for the human race. 


\section{REFERENCES}

[1] Architecture and Engineering for Parks Canada - Public Works and Government Services Canada (1994) Design Guidelines for Accessible Outdoor Recreation Facilities. Ottawa

[2] Bird, William (2004) Natural fit - Can green spaces and biodiversity increase levels of physical activity? Report. RSPB

[3] Dawkins, Richard (1976) The Selfish Gene. New York City: Oxford University Press

[4] Fekete, Albert (2012) Budapesti Nagyparkok akadálymentes kialakításának és biztonságos használatának vizsgálata (Népliget, Városliget, Margitsziget). 4D Tájépítészeti és Kertművészeti Folyóirat, Budapest (ISSN: 1787-6613) különszám: pp. 69-79. (2012)

[5] Fekete, Albert - Koszorú, Lajos - Zöldi, Péter (2009) Budapest Szíve: Reprezentatív kaputérség - Károly Körút, Astoria csomópont, Deák Ferenc tér, Bajcsy Zsilinszky út, József Attila utca és kapcsolódó zöldfelületek megújítása. 4D Tájépítészeti és Kertmúvészeti Folyóirat, Budapest (ISSN: 1787-6613) 13: pp. 3-13.

[6] Fekete, Albert - Kovács, Andrea (2009) 'Az akadálymentesség és egyetemes tervezés kert- és városépítészeti szempontjai, műszaki követelményei’ in Pandula András (ed.) KÉZIKÖNYV - Az akadálymentesség és egyetemes tervezés műszaki-tervezői szempontjai, követelményei (Budapest: Equal Opportunities of Persons with Disabilities non-profit Ltd.)

[7] Fekete, Albert - Planchat, Sophie - Szöbölödi, Anita - Takács, Dániel (2012) Kortárs szabadtérépítészeti alkotások akadálymentességének elemzése Budapest belvárosában. In: Szenteleki, Károly - Szilágyi, Kinga (ed.. 2012) Fenntartható fejlődés, Élhető régió, Élhető települési táj. Budapest, (ISBN:978-963-503-506-2) 216 p. pp. 131-140.(3.)

[8] Fekete, Albert - Szaszák, Gabriella (2014) Inclusive Design for Accessible Public Spaces in the Downtown of Budapest. In: Landscape:a place of cultivation: ECLAS Conference 2014. Book of Proceedings. Porto: University of Porto. pp. 108-113

[9] Hungarian Act No. 53 of 1996 on Nature Conservation <http://www.asser.nl/upload/eel-webroot/www/documents/HUN/ hungary\%20Nature\%20Conservation\%20law.htm> accessed on 19 June 2014

[10] Hungarian act No. 78 of 1997 on the Formation and Protection of the Built Environment

[11] Hungarian act No. 26 of 1998 on the Equalization of Opportunity

[12] Hungarian government decree 253/1997 (20 Dec. 1997) on the National Settlement Planning and Construction Requirements (OTÉK)

[13] Hungarian government decree 78/2008 (03 April 2008) on the Quality Requirements, Marking Off and Operating of the Natural Swimming Waterfronts

[14] Hungarian Central Statistical Office (KSH) (2011): Population census 2011 of Hungary

$<$ http://www.ksh.hu/nepszamlalas/tablak_teruleti_00> accessed on 19 June 2014

[15] Kálmán, ZsóFia - KönCZei, György (2002) A Taigetosztól az esélyegyenlőségig, Budapest: Osiris

[16] Kecskés, Tibor (2014) Az átlátszó építészeti nyelvről [The transparent language of Architecture] in Gulyás, P. (ed.) Müvészet és technikai civilizáció [Art and technical civilization], conference proceedings (Hódmezővásárhely: BKF University of Applied Sciences, Budapest)

[17] Lundell, Ylva (2005) Access to the forests for disabled people. Report. Jönköping: National Board of Forestry March, Skogsstyrelsens förlag

[18] Revita Foundation (2009) Fogyatékos személyek turisztikai igényei. Research program and report. Budapest $<$ http://revitaalapitvany.hu/letoltes/tanulmanyok/turizmus_vezetoi_osszefoglalo.pdf > accessed on 19 June 2014

[19] Szaszák, Gabriella - Fekete, Albert - Szöbölödi, Anita - Takács, Dániel (2012) General principles of barrier free design - Street furniture, motorized traffic, parking based on the example of downtown of Budapest/Egyetemes szabatértervezés Budapest belvárosában - Berendezési tárgyak, jármüközlekedés, parkolás. 4D Tájépítészeti és Kertmüvészeti Folyóirat, Budapest (ISSN: 1787-6613) 25: pp. 41-59. (2012)

[20] SzilágYi, N. Sándor (2013) Nincs olyan, hogy A Magyar Nyelv. In Új Magyar Szó Online $<$ http://www.maszol.ro/index.php/mobil/kultura/20688-szilagyi-n-sandor-nincs-olyan-hogy-a-magyar-nyelv> accessed on 19 June 2014

[21] Wittgenstein, Ludwig [1953] (1999) Philosophical Investigations. Prentice Hall. 1999:53

[22] Wright, Frank Lloyd (1957) interview in Mike Wallace show <https://www.youtube.com/watch?v=DeKzIZAKG3E $>$ accessed on 14 May 2014

\section{SOURCES OF FIGURES}

$\begin{array}{ll}1,2,4,5,6,7,9,10 & \text { Szaszák, Gabriella } \\ 8 & \text { Fekete, Albert } \\ 3 & \text { Kecskés, Tibor } \\ 11,12 & \text { Reference No. [4] }\end{array}$

